\title{
Dissolution Behavior of SiO and Electrochemical Reduction of Dissolved SiO in Molten Chlorides
}

\section{$\operatorname{AUTHOR}(S)$ :}

Ma, Yuanjia; Yamamoto, Takayuki; Yasuda, Kouji; Nohira, Toshiyuki

\section{CITATION:}

Ma, Yuanjia ... [et al]. Dissolution Behavior of SiO and Electrochemical Reduction of Dissolved SiO in Molten Chlorides. ECS Transactions 2020, 98(10): 215-222

\section{ISSUE DATE:}

2020

URL:

http://hdl.handle.net/2433/255866

\section{RIGHT:}

This is the Accepted Manuscript version of an article accepted for publication in ECS Transactions. The Electrochemical Society and IOP Publishing Ltd are not responsible for any errors or omissions in this version of the manuscript or any version derived from it. The Version of Record is available online at https://doi.org/10.1149/09810.0215ecst.; This is not the published version. Please cite only the published version.; この論文は出版社版でありません。引用の際には出版社 版をご確認ご利用ください。 


\title{
Dissolution Behavior of $\mathrm{SiO}_{2}$ and Electrochemical Reduction of Dissolved $\mathrm{SiO}_{2}$ in Molten Chlorides
}

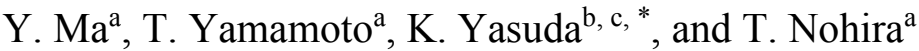 \\ a Institute of Advanced Energy, Kyoto University, Uji 611-0011, Japan \\ ${ }^{b}$ Agency for Health, Safety and Environment, Kyoto 606-8501, Japan \\ ${ }^{c}$ Graduate School of Energy Science, Kyoto University, Kyoto 606-8501, Japan \\ * Present address: Graduate School of Engineering, Kyoto University, \\ Kyoto 606-8501, Japan
}

To develop a new production process for SOG-Si with high productivity and low energy consumption, the structure of silicate ions in molten eutectic $\mathrm{NaCl}-\mathrm{CaCl}_{2}$ containing dissolved $\mathrm{SiO}_{2}$ was investigated by Raman spectroscopy. The existence of $\mathrm{SiO}_{3}{ }^{2-}$ was indicated in melts containing $1.0 \mathrm{~mol} \%$ of $\mathrm{CaSiO}_{3}\left(\mathrm{O}^{2-} / \mathrm{SiO}_{2}=1.0\right)$. When $1.0 \mathrm{~mol} \%$ of $\mathrm{CaO}$ was further added to the melt $\left(\mathrm{O}^{2-} / \mathrm{SiO}_{2}=\right.$ 2.0), the existence of $\mathrm{SiO}_{4}{ }^{4-}$ was indicated. Cyclic voltammetry and potentiostatic electrolysis were conducted in molten $\mathrm{NaCl}-\mathrm{CaCl}_{2}$ with different silicate ions. From cyclic voltammograms, XRD analysis and SEM observation, silicate ions with different structure indicated different electrochemical reduction behavior; and the $\mathrm{SiO}_{3}{ }^{2-}$ ion is likely to be more suitable than $\mathrm{SiO}_{4}{ }^{4-}$ ion for the electrodeposition of $\mathrm{Si}$.

\section{Introduction}

Photovoltaic (PV) power generation is considered as a source of clean and inexhaustible energy, which could substitute the conventional fossil-fuel power generation. The global production of PV cells achieved $102.4 \mathrm{GW}$ in 2018, approximately 350 times the value in 2000 (1). Since crystalline silicon solar cells accounted for $96.9 \%$ of the worldwide production in 2018 (2), they are expected to remain mainstream in the PV industry for the time being. Thus, the global demand for high-purity crystalline $\mathrm{Si}$, which is known as solargrade $\mathrm{Si}(\mathrm{SOG}-\mathrm{Si}$ ), will also continue to increase in the future.

To develop a new production process for $\mathrm{SOG}-\mathrm{Si}$, experimental studies such as purification of metallurgical-grade silicon (3) and metallothermic reduction of silicon halides by metal reductants (4) have been conducted. Over the past two decades, we have been studying the electrochemical reduction of solid $\mathrm{SiO}_{2}$ to $\mathrm{Si}$ in molten $\mathrm{CaCl}_{2}$ to as a new production process for SOG-Si (5-7). In molten $\mathrm{CaCl}_{2}$, electrochemical reduction of insulating $\mathrm{SiO}_{2}$ proceeds by using a $\mathrm{SiO}_{2}$ contacting electrode, which provides a threephase interface of conductor $/ \mathrm{SiO}_{2} / \mathrm{CaCl}_{2}$.

$$
\mathrm{SiO}_{2}(s)+4 \mathrm{e}^{-} \rightarrow \mathrm{Si}(s)+2 \mathrm{O}^{2-}
$$

With the aim of efficient recovery of reduced $\mathrm{Si}$, we also proposed an electrochemical reduction process of $\mathrm{SiO}_{2}$ using a liquid $\mathrm{Zn}$ cathode in molten $\mathrm{CaCl}_{2}(8-10)$. The overall process consists of three major steps: electrolysis, precipitation, and refining. In the 
electrolysis step, solid $\mathrm{SiO}_{2}$ is reduced to form $\mathrm{Si}-\mathrm{Zn}$ liquid alloy. Then, solid $\mathrm{Si}$ is precipitated by decreasing the temperature of the liquid $\mathrm{Si}-\mathrm{Zn}$ alloy in the precipitation step. The recovered $\mathrm{Si}$ is subjected to a refining step that comprises vacuum refining to remove residual $\mathrm{Zn}$ and directional solidification to manufacture SOG-Si ingots.

In our previous study, we found that direct electrochemical reduction of $\mathrm{SiO}_{2}$ mainly occurred at the three-phase interface of $\mathrm{Zn} / \mathrm{SiO}_{2} / \mathrm{CaCl}_{2}$. Although, the liquid $\mathrm{Ca}-\mathrm{Zn}$ alloy, which formed at negative potentials, also contributed to the indirect reduction of $\mathrm{SiO}_{2}$ below the $\mathrm{Zn} / \mathrm{CaCl}_{2}$ interface, i.e. in the liquid $\mathrm{Zn}$ cathode, the current efficiency was low since only part of $\mathrm{Ca}-\mathrm{Zn}$ alloy contributed to the reduction of $\mathrm{SiO}_{2}(10)$. In order to improve the productivity of the process, we focused on the electrochemical reduction of dissolved $\mathrm{SiO}_{2}$, i.e., silicate ions $\left(\mathrm{SiO}_{4}{ }^{4-}, \mathrm{SiO}_{3}{ }^{2-}, \mathrm{Si}_{2} \mathrm{O}_{5}{ }^{2-}\right.$ etc.). When $\mathrm{O}^{2-}$ ion is added into molten salt, the dissolution of $\mathrm{SiO}_{2}$ could be expressed as

$$
x \mathrm{SiO}_{2}(s)+y \mathrm{O}^{2-} \rightarrow \mathrm{Si}_{x} \mathrm{O}_{(2 x+y)}^{2 y-}
$$

Electrodeposition of crystalline Si film from silicate ions has been reported by Bard and co-workers $(11,12)$. However, the structure of silicate ions has not been investigated.

In the present study, we focused on eutectic $\mathrm{NaCl}-\mathrm{CaCl}_{2}$, which has a lower melting point $(777 \mathrm{~K})$ than that of pure $\mathrm{CaCl}_{2}(1045 \mathrm{~K})$. The structure of silicate ions in molten eutectic $\mathrm{NaCl}-\mathrm{CaCl}_{2}$ with various concentrations of $\mathrm{CaO}$ was investigated by Raman spectroscopy. In our previous study, we have found that the structure of dissolved $\mathrm{SiO}_{2}$ is identical to that of dissolved $\mathrm{CaSiO}_{3}$ when the ratio of $\mathrm{O}^{2-} / \mathrm{SiO}_{2}$ is less than 1.0. Thus, $\mathrm{CaSiO}_{3}$ was used as the source of $\mathrm{SiO}_{3}{ }^{2-}$ ion, and $\mathrm{CaO}$ as the source of $\mathrm{O}^{2-}$ ion in this study. Also, electrochemical reduction of silicate ions was investigated at a solid graphite substrate, as the preliminary study for liquid $\mathrm{Zn}$ cathode.

\section{Experimental}

All experiments were conducted in a dry Ar atmosphere at $1023 \mathrm{~K}$.

Structural Analysis of Silicate Ions by Raman Spectroscopy

$\mathrm{NaCl}$ and $\mathrm{CaCl}_{2}$ powders (FUJIFILM Wako Pure Chemical Corp., reagent grade) were mixed in an eutectic composition $\left(\mathrm{NaCl}: \mathrm{CaCl}_{2}=47.9: 52.1 \mathrm{~mol} \%\right)$, and then certain amounts of $\mathrm{CaO}$ (FUJIFILM Wako Pure Chemical Corp., reagent grade, 0 or $1.0 \mathrm{~mol} \%$ ) and $\mathrm{CaSiO}_{3}$ (ALDRICH Chemistry, 200 mesh, 99\%, $1.0 \mathrm{~mol} \%$ ) powders were added to the eutectic mixture. The mixture was loaded into a graphite crucible (Toyo Tanso Co., Ltd., IG-110 grade, o.d. $55 \mathrm{~mm} \times$ i.d. $49 \mathrm{~mm} \times$ height $150 \mathrm{~mm}$ ) and dried under vacuum at $453 \mathrm{~K}$ for 2 days, then $723 \mathrm{~K}$ for 1 day. After the temperature was raised to $1023 \mathrm{~K}$ and maintained at that temperature for 1 day to sufficiently dissolve $\mathrm{CaO}$ and $\mathrm{CaSiO}_{3}$, the salt was sampled by a Pyrex tube.

The sampled salt was then loaded into a Pt pan (Rigaku Corp., o.d. $5 \mathrm{~mm} \times$ height 2.5 $\mathrm{mm}$ ) and was placed in an air-tight high-temperature stage (Japan High Tech Co., Ltd., 10042). After the mixture was heated to $1023 \mathrm{~K}$, the structure of silicate ions was investigated by Raman spectroscopy (Tokyo Instruments, Nanofinder 30). Figure 1 shows a schematic drawing of experimental apparatus for Raman spectroscopy. 


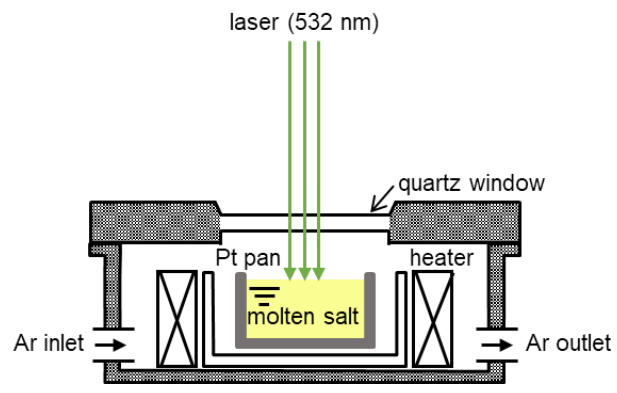

Figure 1. Schematic illustration of experimental apparatus for Raman spectroscopy of molten salt.

\section{Electrochemical Reduction of Silicate Ions}

$\mathrm{NaCl}$ and $\mathrm{CaCl}_{2}$ powders were mixed in an eutectic composition and loaded into a graphite crucible (Toyo Tanso Co., Ltd., IG-110 grade, o.d. $80 \mathrm{~mm} \times$ i.d. $70 \mathrm{~mm} \times$ height $200 \mathrm{~mm}$ ). The eutectic mixture was dried under vacuum at $453 \mathrm{~K}$ for 2 days and $723 \mathrm{~K}$ for 1 day. After the temperature was raised to $1023 \mathrm{~K}$, certain amounts of $\mathrm{CaO}(0$ or $1.0 \mathrm{~mol} \%)$ and $\mathrm{CaSiO}_{3}(1.0 \mathrm{~mol} \%)$ powders were added to the eutectic mixture.

Figure 2 shows a schematic drawing of experimental apparatus for electrochemical reduction of silicate ions. As the working electrodes, a flag-like graphite plate (Toyo Tanso Co., Ltd., $3 \mathrm{~mm} \times 3 \mathrm{~mm} \times$ thickness $0.5 \mathrm{~mm}$ ) was used for cyclic voltammetry and that with a size of $10 \mathrm{~mm} \times 10 \mathrm{~mm}$ was used for electrolysis. The counter electrodes were glasslike carbon (Tokai Carbon Co., Ltd., diam.: $3.0 \mathrm{~mm}$ ) for cyclic voltammetry and graphite square bar (Toyo Tanso Co., Ltd., $5 \mathrm{~mm} \times 5 \mathrm{~mm} \times$ height $50 \mathrm{~mm}$ ) for electrolysis. A Si square bar (Furuuchi Chemical Corp., $5 \mathrm{~mm} \times 5 \mathrm{~mm} \times$ height $50 \mathrm{~mm}, 10 \mathrm{~N}$ ) was used as the reference electrode.

The obtained samples were washed in a $\mathrm{HCl}$ solution $(\mathrm{pH}=1)$ at $333 \mathrm{~K}$ and analyzed by X-ray diffraction (XRD, Rigaku, Ultima 4, $\mathrm{Cu}-K \alpha, \lambda=1.5418 \AA, 40 \mathrm{kV}, 40 \mathrm{~mA}$ ) and SEM (Phenom, Pro-SED).

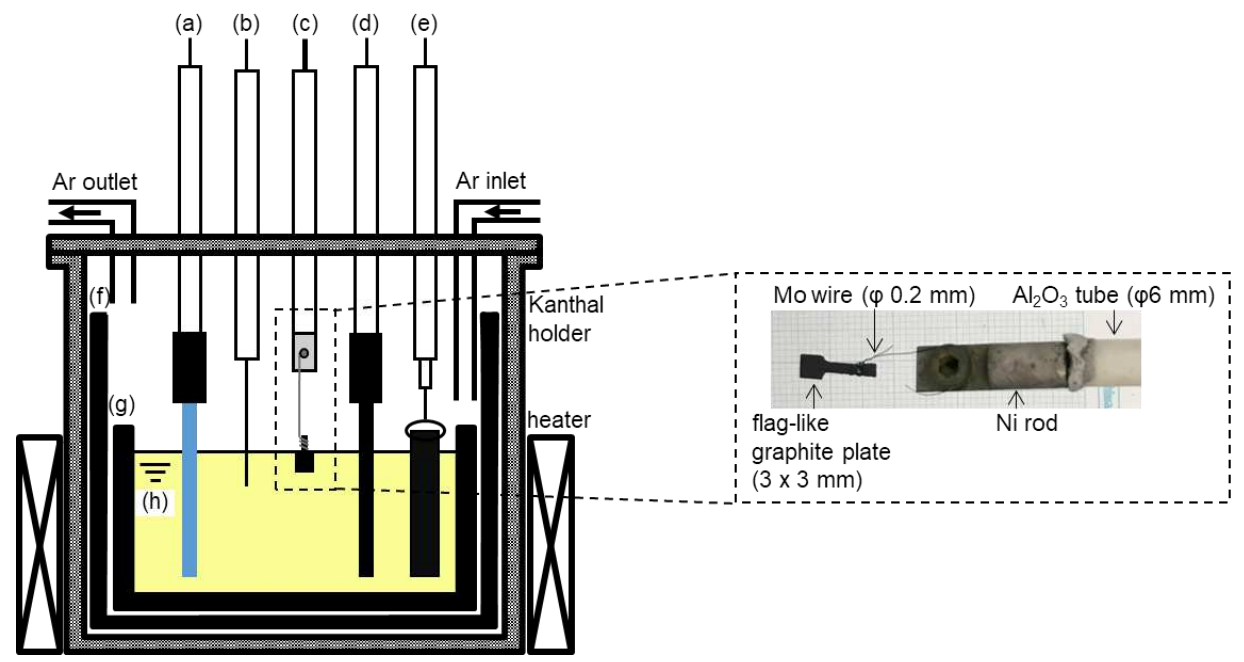

Figure 2. Schematic illustration of the electrolysis cell. (a) Si reference electrode, (b) $\mathrm{Na}^{+} / \mathrm{Na}$ dynamic reference electrode on a Mo wire, (c) flag-like graphite working electrode, (d) glass-like carbon counter electrode, (e) graphite counter electrode, (f) graphite holder, (g) graphite crucible, and (h) molten $\mathrm{NaCl}-\mathrm{CaCl}_{2}$ containing $\mathrm{CaO}$ and $\mathrm{CaSiO}_{3}$. 


\section{Results and Discussion}

\section{$\underline{\text { Structure of Silicate Ions }}$}

Figure 3 shows Raman spectra of molten (a) $\mathrm{NaCl}-\mathrm{CaCl}_{2}-1.0 \mathrm{~mol}_{0} \mathrm{CaSiO}_{3}$ and (b) $\mathrm{NaCl}-\mathrm{CaCl}_{2}-1.0 \mathrm{~mol} \% \mathrm{CaO}-1.0 \mathrm{~mol}^{\circ} \mathrm{CaSiO}_{3}$ at $1023 \mathrm{~K}$. Within the wave number range of 700-1200 $\mathrm{cm}^{-1}$, a strong band at $972 \mathrm{~cm}^{-1}$ and weak bands at $915,1051 \mathrm{~cm}^{-1}$ were observed for molten salt (a). On the other hand, a strong band was detected at $830 \mathrm{~cm}^{-1}$ for molten salt (b). The main Raman bands for the stretch vibration of $\mathrm{Si}-\mathrm{O}$ structures have been reported as $850-870 \mathrm{~cm}^{-1}$ for $\mathrm{SiO}_{4}{ }^{4-}, 905-920 \mathrm{~cm}^{-1}$ for $\mathrm{Si}_{2} \mathrm{O}_{7}{ }^{6-}, 950-970 \mathrm{~cm}^{-1}$ for $\mathrm{SiO}_{3}{ }^{2-}$, and $1050-1100 \mathrm{~cm}^{-1}$ for $\mathrm{Si}_{2} \mathrm{O}_{5}{ }^{2-}$, respectively (13-17). Therefore, the main structure is $\mathrm{SiO}_{3}{ }^{2-}$ in molten salt (a) and $\mathrm{SiO}_{4}{ }^{4-}$ in molten salt (b), which is consistent well with the $\mathrm{O}^{2-} / \mathrm{SiO}_{2}$ ratio in the melts. The weak bands of $\mathrm{Si}_{2} \mathrm{O}_{7}{ }^{6-}$ and $\mathrm{Si}_{2} \mathrm{O}_{5}{ }^{2-}$ ions are observed due to the disproportionation reaction of $\mathrm{SiO}_{3}{ }^{2-}$ ion (reaction [3]).

$$
4 \mathrm{SiO}_{3}{ }^{2-} \rightarrow \mathrm{Si}_{2} \mathrm{O}_{7}{ }^{6-}+\mathrm{Si}_{2} \mathrm{O}_{5}{ }^{2-}
$$
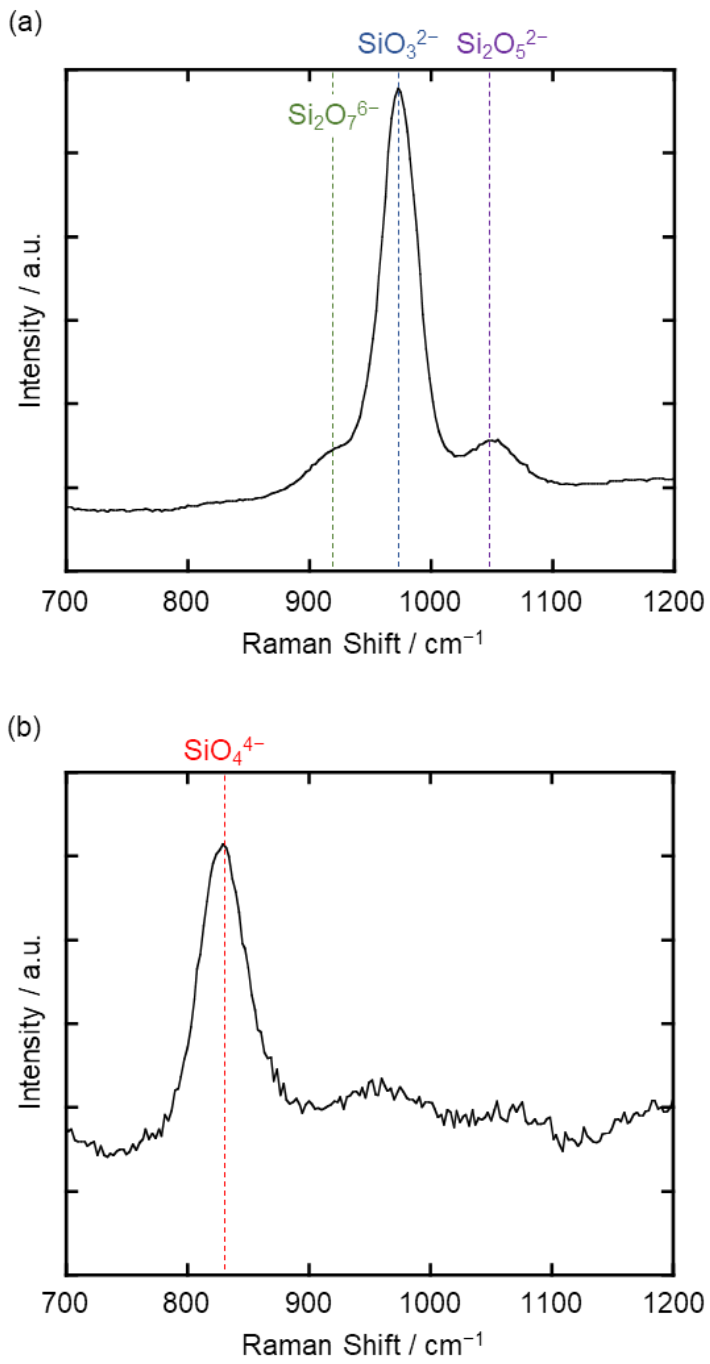

Figure 3. Raman spectra of molten $\mathrm{NaCl}-\mathrm{CaCl}_{2}$ containing (a) $1.0 \mathrm{~mol} \% \mathrm{CaSiO}_{3}$, and (b) $1.0 \mathrm{~mol} \% \mathrm{CaO}-1.0 \mathrm{~mol} \% \mathrm{CaSiO}_{3}$ at $1023 \mathrm{~K}$. 


\section{Electrochemical Reduction of Silicate Ions}

Figure 4 (a) shows cyclic voltammograms at a graphite electrode in molten $\mathrm{NaCl}-$ $\mathrm{CaCl}_{2}$ before and after the addition of $1.0 \mathrm{~mol} \%$ of $\mathrm{CaSiO}_{3}$. The cathodic current observed in blank melt is likely due to the intercalation of $\mathrm{Na}$ or $\mathrm{Ca}$ metal into graphite. After the addition of $\mathrm{CaSiO}_{3}$, cathodic currents increase from $1.2 \mathrm{~V}$ (vs. $\mathrm{Na}^{+} / \mathrm{Na}$ ), suggesting the electrochemical reduction of $\mathrm{SiO}_{3}{ }^{2-}$ ion. The sharp increase in cathodic current around 0.6 $\mathrm{V}$ is considered as the formation of $\mathrm{Na}-\mathrm{Si}$ or $\mathrm{Ca}-\mathrm{Si}$ alloy. Figure 4 (b) shows the voltammogram measured after the addition of $1.0 \mathrm{~mol} \%$ of $\mathrm{CaO}$ and $1.0 \mathrm{~mol} \% \mathrm{CaSiO}_{3}$. Cathodic currents were observed from the rest potential $(1.8 \mathrm{~V})$, which suggests the electrochemical reduction of $\mathrm{SiO}_{4}{ }^{4-}$ ion. The sharp increase from $0.6 \mathrm{~V}$ is supposed to be the same as that for $\mathrm{SiO}_{3}{ }^{2-}$ ion in Figure 4 (a).

(a)

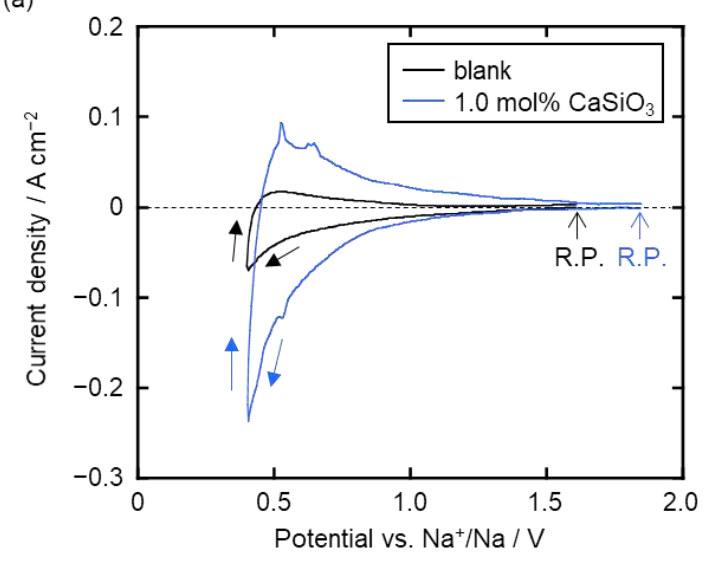

(b)

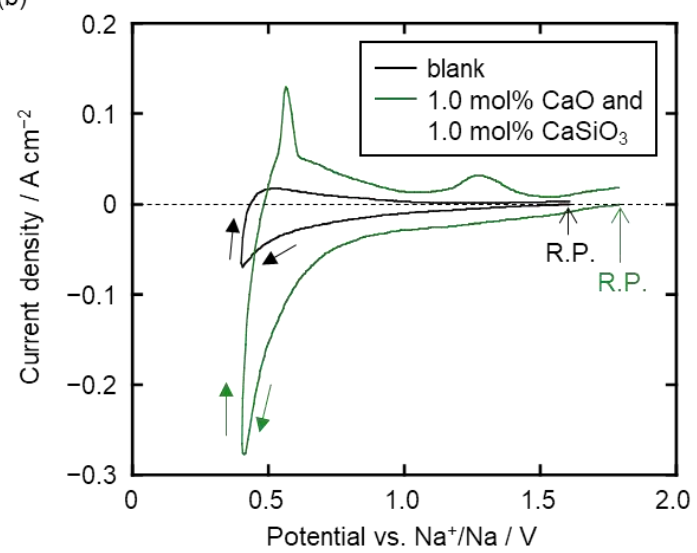

Figure 4. Cyclic voltammograms at a graphite electrode in molten $\mathrm{NaCl}-\mathrm{CaCl}_{2}$ before and after the addition of (a) $1.0 \mathrm{~mol} \%$ of $\mathrm{CaSiO}_{3}$, and (b) $1.0 \mathrm{~mol} \%$ of $\mathrm{CaO}$ and $1.0 \mathrm{~mol} \%$ of $\mathrm{CaSiO}_{3}$ at $1023 \mathrm{~K}$. Scan rate: $50 \mathrm{mV} \mathrm{s}^{-1}$.

On the basis of the voltammetric results, potentiostatic electrolysis was conducted at $0.90,0.70$, and $0.50 \mathrm{~V}$ for $-14 \mathrm{C} \mathrm{cm}^{-2}$ in molten $\mathrm{NaCl}-\mathrm{CaCl}_{2}$ containing $1.0 \mathrm{~mol} \%$ of $\mathrm{CaSiO}_{3}$ (molten salt (a)), and $1.0 \mathrm{~mol} \%$ of $\mathrm{CaO}$ and $1.0 \mathrm{~mol} \%$ of $\mathrm{CaSiO}_{3}$ (molten salt (b)). The optical images of the graphite substrate and electrolyzed samples are shown in Figure 5. For samples obtained in molten salt (a), small amount of deposits were observed at 0.90 $\mathrm{V}$ and $0.50 \mathrm{~V}$, and quite amount of deposit in brown color at $0.70 \mathrm{~V}$. For samples obtained in (b), no significant deposit was observed at $0.90 \mathrm{~V}$, deposits in brown and gray colors were obtained at $0.70 \mathrm{~V}$, and deposit in gray color at $0.50 \mathrm{~V}$.

Figure 6 shows XRD patterns of a graphite substrate and the electrolyzed samples. For samples obtained at 0.90 and $0.70 \mathrm{~V}$ in molten salt (a), the formation of $\mathrm{Si}$ was confirmed, indicating that the increase in cathodic current from $1.2 \mathrm{~V}$ in Figure 4 (a) is the electrochemical reduction of $\mathrm{SiO}_{3}{ }^{2-}$ ion to solid $\mathrm{Si}$.

$$
\mathrm{SiO}_{3}^{2-}+4 \mathrm{e}^{-} \rightarrow \mathrm{Si}(s)+3 \mathrm{O}^{2-}
$$

Since $\mathrm{CaSi}_{2}$ was identified for the sample at $0.50 \mathrm{~V}$, the sharp increase from $0.6 \mathrm{~V}$ corresponds the formation of $\mathrm{CaSi}_{2}$.

$$
2 \mathrm{Si}(s)+\mathrm{Ca}^{2+}+2 \mathrm{e}^{-} \rightarrow \mathrm{CaSi}_{2}(s)
$$


For samples obtained in molten salt (b), only graphite was detected at $0.90 \mathrm{~V}$. The existence of $\mathrm{Si}$ was confirmed at $0.70 \mathrm{~V}$, and both $\mathrm{Si}$ and $\mathrm{CaSi}_{2}$ were detected at $0.50 \mathrm{~V}$. Since $\mathrm{Si}$ deposition was only observed at potentials more negative than $0.70 \mathrm{~V}$, the electrochemical reduction of $\mathrm{SiO}_{4}{ }^{4-}$ ion to $\mathrm{Si}$ is considered to be more difficult than that of $\mathrm{SiO}_{3}{ }^{2-}$ ion. Similarly, the formation of $\mathrm{CaSi}_{2}$ seems to be less favorable for $\mathrm{SiO}_{4}{ }^{4-}$ ion compared with $\mathrm{SiO}_{3}{ }^{2-}$ ion.

Figure 7 shows surface SEM images of deposits. In molten salt (a), wire-like Si was obtained at $0.90 \mathrm{~V}$ and particle $\mathrm{Si}$ at $0.70 \mathrm{~V}$. Dense $\mathrm{CaSi}_{2}$ was observed at $0.50 \mathrm{~V}$. For samples obtained in molten salt (b), wire-like Si was observed at $0.70 \mathrm{~V}$ and particle $\mathrm{Si}$ at $0.50 \mathrm{~V}$.

From the results of XRD and SEM, the electrodeposition of $\mathrm{Si}$ from $\mathrm{SiO}_{3}{ }^{2-}$ ion started from a more positive potential than that of $\mathrm{SiO}_{4}{ }^{4-}$ ion. Thus, $\mathrm{SiO}_{3}{ }^{2-}$ ion will be more suitable for the electrodeposition of $\mathrm{Si}$ at liquid $\mathrm{Zn}$ cathode as well as at solid graphite electrode.

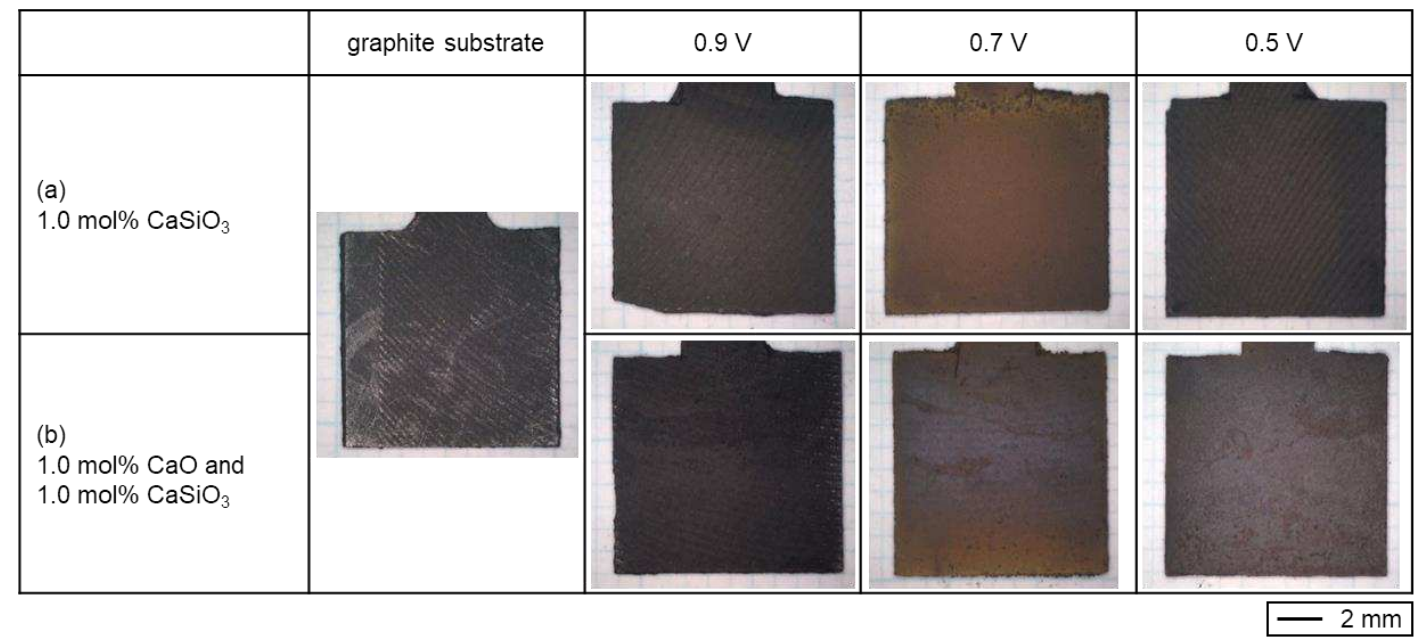

Figure 5. Optical images of the graphite substrate and samples obtained by electrolysis at graphite plates in molten $\mathrm{NaCl}-\mathrm{CaCl}_{2}$ containing (a) $1.0 \mathrm{~mol} \%$ of $\mathrm{CaSiO}_{3}$, and (b) 1.0 $\mathrm{mol} \%$ of $\mathrm{CaO}$ and $1.0 \mathrm{~mol} \%$ of $\mathrm{CaSiO}_{3}$. Charge density: $-14 \mathrm{C} \mathrm{cm}^{-2}$. 
(a)

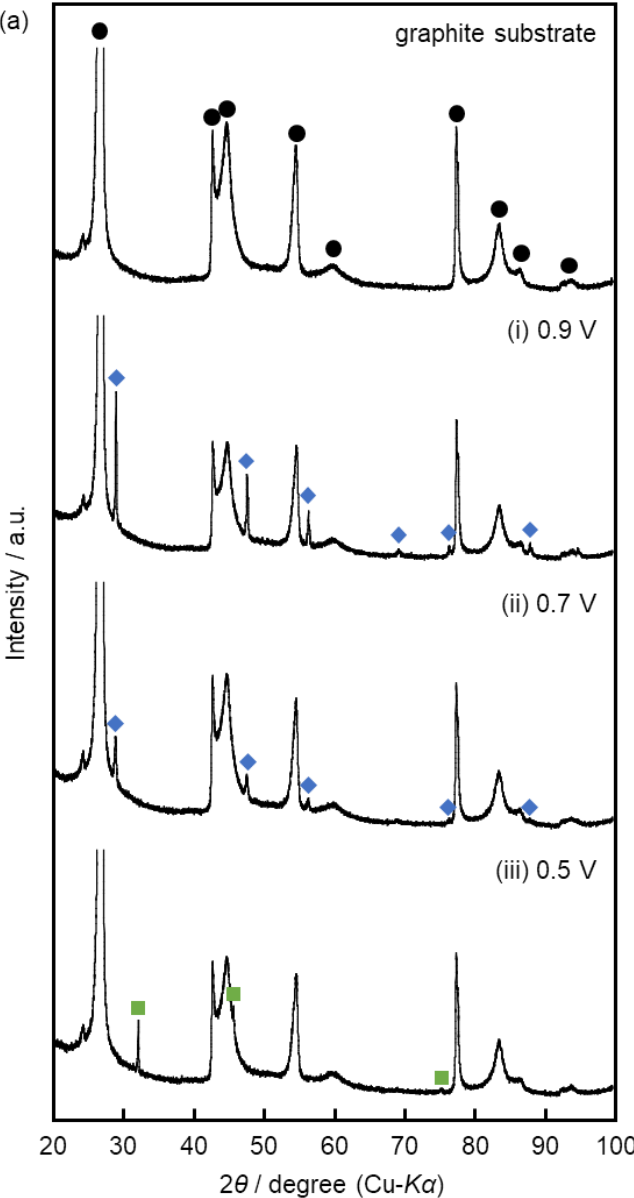

- Si $\quad(00-026-1481)$

- $\mathrm{CaSi}_{2} \quad(00-047-1518)$

- graphite (00-056-0159)

(b)

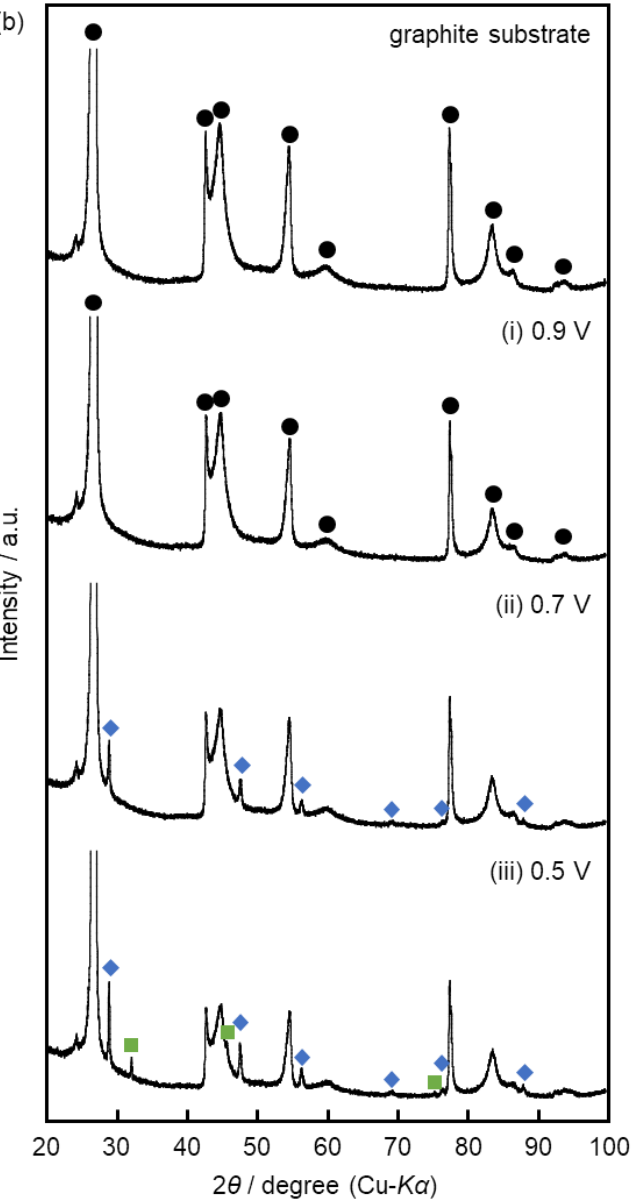

Figure 6. XRD patterns of the graphite substrate and samples obtained by electrolysis at graphite plates in molten $\mathrm{NaCl}-\mathrm{CaCl}_{2}$ containing (a) $1.0 \mathrm{~mol} \%$ of $\mathrm{CaSiO}_{3}$, and (b) 1.0 $\mathrm{mol} \%$ of $\mathrm{CaO}$ and $1.0 \mathrm{~mol} \%$ of $\mathrm{CaSiO}_{3}$. Charge density: $-14 \mathrm{C} \mathrm{cm}^{-2}$.

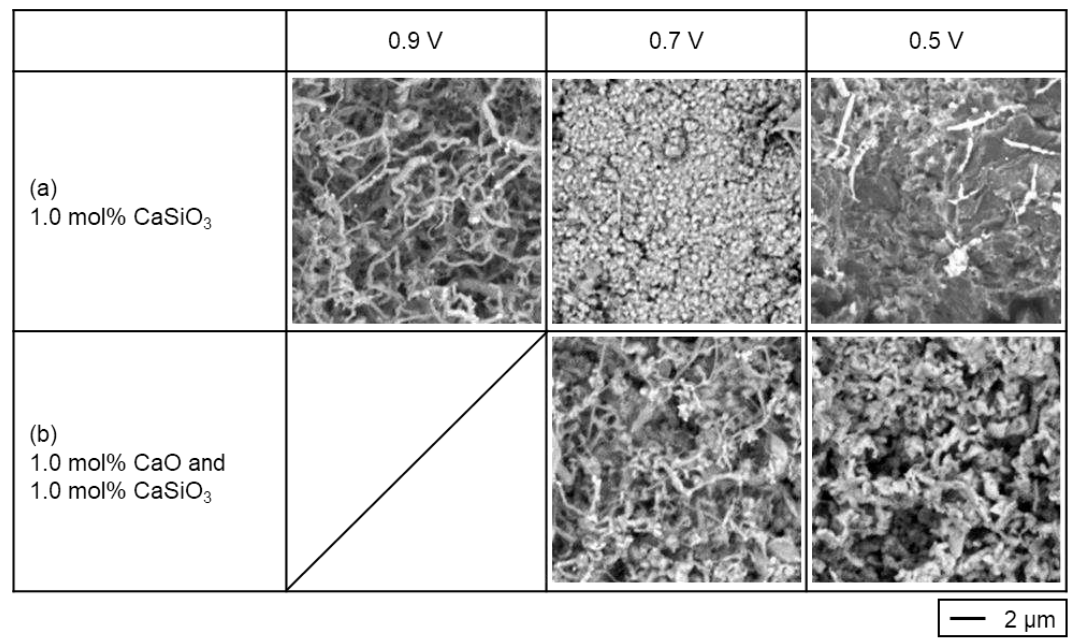

Figure 7. SEM images of the samples obtained by electrolysis at graphite plates in molten $\mathrm{NaCl}-\mathrm{CaCl}_{2}$ containing (a) $1.0 \mathrm{~mol} \%$ of $\mathrm{CaSiO}_{3}$, and (b) $1.0 \mathrm{~mol} \%$ of $\mathrm{CaO}$ and $1.0 \mathrm{~mol} \%$ of $\mathrm{CaSiO}_{3}$. Charge density: $-14 \mathrm{C} \mathrm{cm}^{-2}$. 


\section{Conclusion}

The structural analysis and electrochemical reduction of silicate ions at the solid graphite substrate were conducted as the preliminary study for liquid $\mathrm{Zn}$ cathode. The structure of silicate ions in molten $\mathrm{NaCl}-\mathrm{CaCl}_{2}$ containing (a) $1.0 \mathrm{~mol} \%$ of $\mathrm{CaSiO}_{3}$ and (b) $1.0 \mathrm{~mol} \%$ of $\mathrm{CaO}$ and $1.0 \mathrm{~mol}^{\%}$ of $\mathrm{CaSiO}_{3}$ was investigated by Raman spectroscopy. The main structure is $\mathrm{SiO}_{3}{ }^{2-}$ ion in molten salt (a) and $\mathrm{SiO}_{4}{ }^{4-}$ ion in molten salt (b), which is consistent well with the $\mathrm{O}^{2-} / \mathrm{SiO}_{2}$ ratio in the melts. In molten salt (a), electrodeposition of $\mathrm{Si}$ was confirmed at $0.70-0.90 \mathrm{~V}$ and formation of $\mathrm{CaSi}_{2}$ at $0.50 \mathrm{~V}$. In molten salt (b), pure $\mathrm{Si}$ deposition was only confirmed at $0.70 \mathrm{~V}$ and the mixture of $\mathrm{Si}$ and $\mathrm{CaSi}_{2}$ was observed at $0.50 \mathrm{~V}$. Thus, $\mathrm{SiO}_{3}{ }^{2-}$ ion is likely to be more suitable for the electrodeposition of $\mathrm{Si}$ at liquid $\mathrm{Zn}$ cathode as well as at solid graphite electrode.

\section{Acknowledgement}

This study was partially supported by Grant-in-Aid for Scientific Research A, Grant Number 16H02410, from the Japan Society for the Promotion of Science (JSPS) and the Joint Usage/Research Program on Zero-Emission Energy Research, Institute of Advanced Energy, Kyoto University (ZE30A-04, ZE31A-05).

\section{Reference}

1. Industrial Rare Metal 2019, Arumu Publ. Co. (2019).

2. Photovoltaic Market 2019, RTS Corp. (2019).

3. X. Ma, T. Yoshikawa and K. Morita, Sep. Purif. Technol., 125, 264 (2014).

4. S. Honda, M. Yasueda, S. Hayashida and M. Yamaguchi: Japanese Patent, Toku Kai H19-145663 (2007).

5. T. Nohira, K. Yasuda and Y. Ito, Nat. Mater., 2, 397 (2003).

6. K. Yasuda, T. Nohira, R. Hagiwara and Y. H. Ogata, J. Electrochem. Soc., 154, E95 (2007).

7. T. Toba, K. Yasuda, T. Nohira, X. Yang, R. Hagiwara, K. Ichitsubo, K. Masuda and T. Homma, Electrochemistry, 81, 559 (2013).

8. T. Nohira, A. Ido, T. Shimao, X. Yang, K. Yasuda, R. Hagiwara and T. Homma, ECS Trans., 75(15), 17 (2016).

9. K. Yasuda, T. Shimao, R. Hagiwara, T. Homma and T. Nohira, J. Electrochem. Soc., 164, H5049 (2017).

10. Y. Ma, A. Ido, K. Yasuda, R. Hagiwara and T. Nohira, J. Electrochem. Soc., 166, D162 (2019).

11. X. Yang, L. Ji, X. Zou, T. Lim, J. Zhao, E. T. Yu and A. J. Bard, Angew. Chem. Int. Ed., 56, 15078 (2017).

12. X. Zou, L. Ji, J. Ge, D. R. Sadoway, E. T. Yu and A. J. Bard, Nat. Commun., 10, 5772 (2019).

13. C. R. Masson, Jour. Iron Steel Inst., 210, 89 (1972).

14. S. A. Brawer and W. B. White, Chem. Phys., 63, 2421 (1975).

15. P. Sen and M. Thorpe, Phys. Rev. B, 15, 4030 (1977).

16. F. L. Galeener, Phys. Rev. B, 19, 4292 (1979).

17. H. Verweij, Jour. Non-Cryst. Solids, 33, 41 (1979). 